\title{
Paleogene fish otoliths (Teleostei) from the Subsilesian and Ždánice units in Moravia
}

\author{
Rostislav BrzobohatÝ \& Miroslav Bubík
}

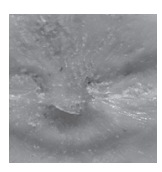

\begin{abstract}
The Oligocene fish otolith fauna from the Subsilesian Unit of Western Carpathians in Moravia is described for the first time. The otoliths were found in pebbly mudstones and slumps interfingering with the Menilite Formation while hemipelagites of the formation are barren in otoliths. The otoliths represent deep-sea taxa dominated by myctophids. Two different otolith-based assemblages were distinguished: lower-slope assemblage with Vinciguerria sp., 'Phosichthys' triquetrus (Brzobohatý), 'Diaphus' alcoholicus Brzobohatý \& Nolf, Oligophus moravicus (Pauca), Melanonus triangulus (Robba), Palaeogadus cf. intergerinus Daniltshenko, Coryphaenoides sp., and upper-slope assemblage with Xenodermichthys cf. senesi Nolf \& Brzobohatý, Scopelarchus sp., 'Diaphus' cf. excavatus (Šulc), 'Diaphus' sp., and ?Synaphobranchidae indet. Otoliths are interpreted as in situ fauna, although the upper-slope assemblage may contain reworked specimens from the Eocene. Cutthroat eel (Synaphobranchidae) represents probably the first fossil otolith record of the family. The otolith fauna from the Subsilesian Unit can be compared with faunas of the Pouzdřany Marl, Ranzano Formation of Northern Apennines and IPM1 ecostratigraphic Zone of the Polish Carpathians. The otoliths document palaeomediterranean deep-water fish fauna strictly different from the modern Mediterranean fishes. • Key words: Teleostei, otoliths, Eocene, Oligocene, Outer Flysch Carpathians.
\end{abstract}

Brzoвohatý, R. \& Bubík, M. 2019. Paleogene fish otoliths (Teleostei) from the Subsilesian and Ždánice units in Moravia. Bulletin of Geosciences 94(1), 101-114 (7 figures, 2 tables). Czech Geological Survey, Prague. ISSN 1214-1119. Manuscript received June 12, 2018; accepted in revised form January 17, 2019; published online March 11, 2019; issued March 31, 2019.

Rostislav Brzobohatý, Department of Geology, Masaryk University Brno, Kotlářská 2, 61137 Brno; rosta@sci.muni. $c z \bullet$ Miroslav Bubik, Czech Geological Survey, Leitnerova 22, 60200 Brno, Czech Republic

In the Outer Flysch Carpathians of Moravia, the first fish otolith fauna was known from the Pouzdřany and Ždánice units. In the Pouzdřany Unit, very rich otolith assemblages were described from the Pouzdrrany Marl (Schubert 1906, 1908; Brzobohatý 1967, 1982; Kučera 1994). Brzobohatý \& Krhovský (1998) published a synopsis of fish otolith taxa from these strata together with palaeogeographic and stratigraphic interpretation. The otolith fauna of the classic locality "Pouzdřany - Wine cellars" reflects a midwater environment with normal salinity and palaeodepth between 300 and $400 \mathrm{~m}$, whereas in the locality "Pouzdřany - Above the mill" otoliths indicate deeper habitats between 500 and $700 \mathrm{~m}$. With comparable facies characters, the Pouzdrrany Marl otolith fauna shares 3 of the 13 nominal species with the Kiscell Clay fauna from Hungary (Nolf \& Brzobohatý 1994).

In the Ždánice Unit, otoliths occur in the Sheshory Marl and the Menilite Formation (Pauca 1931, Weiler 1935, Brzobohatý \& Kalabis 1978, Brzobohatý 1981). The Sheshory Marl contains a mesopelagic otolith association with 'Diaphus' longirostris (= Oligophus moravicus), Valenciennellus sp., and epipelagic Bregmaceros catulus. Shallower dwelling fishes (Palaeogadus, Lepidopus) occur in the lower part of the Menilite Formation (Subchert, Chert, and Dynów members). Otoliths of Oligophus in the upper part of the formation (Šitbořice Member) prove a return of deep-water fauna.

So far no otoliths were reported from the Subsilesian Unit which represents a northwestern continuation of the Ždánice Unit with similar depositional history and palaeogeographical position. This paper brings information on the new otolith fauna recovered from the Menilite Formation and lower Oligocene pebbly mudstones of the Subsilesian Unit together with a revision of the older data from the Ždánice Unit.

\section{Geological setting}

The Outer Flysch Carpathians are allochthonous rootles accretionary wedge formed by polyphase deformation of uppermost Jurassic to early Miocene deep-sea sediments deposited in sub-basins of northern Tethys near the North European Platform margin. Orogenetic events started in the Eocene and Outer Carpathians gained definite structure in the middle Miocene. The Waschberg, Subsilesian 


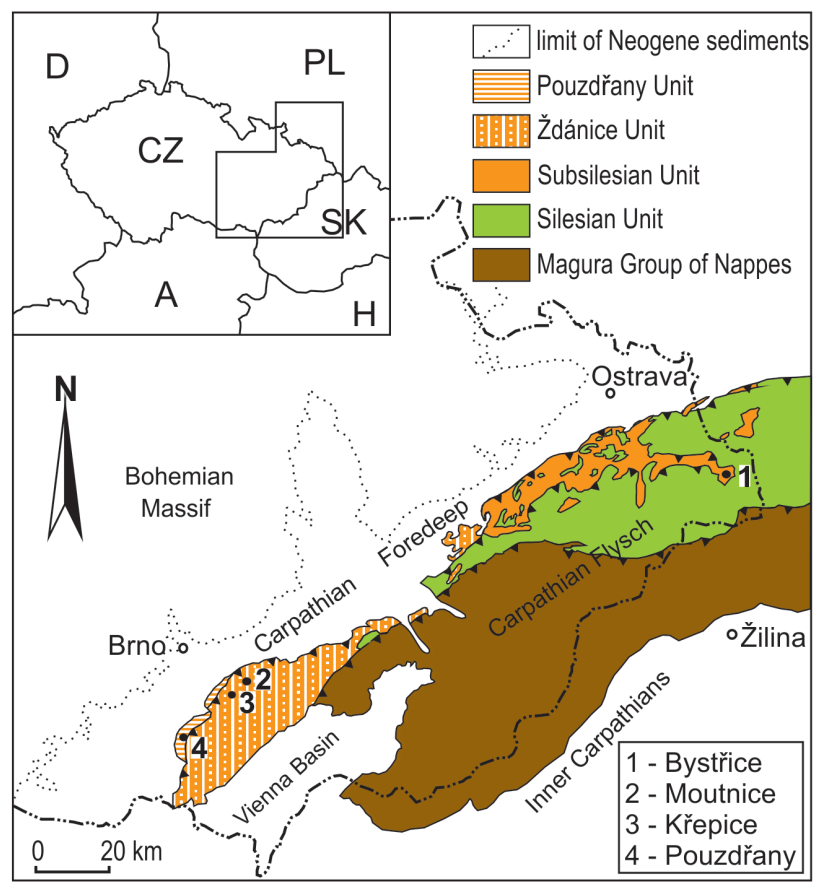

Figure 1. Overview tectonic map of the Outer Flysch Carpathians in Moravia with the position of studied sections.

and Ždánice units, united by some authors to the single Waschberg-Ždánice-Subsilesian Unit, form external part of the Outer Group of Nappes (Menilite-Krosno Group) of the Outer Carpathians (Fig. 1). The Subsilesian Unit differs from Ždánice Unit by its stronger deformation, but its lithology and stratigraphy are very similar to those of later one (Pícha et al. 2006). The Pouzdřany Unit forms tectonic slices of upper Eocene to lower Miocene sediments along the outer margin of the Ždánice Unit (Krhovský et al. 1992, Švábenická et al. 2007).

All mentioned units represent the sedimentary fill of single marine domain between the margin of the North
European Platform and central part of the Silesian Basin. The Waschberg-Ždánice-Subsilesian sedimentary area possesses an oceanic character until the end of the Eocene. During the early Oligocene, a gradual isolation from the world ocean resulted in the deposition of organic-rich pelagites of the Menilite Formation. The Pouzdřany sedimentary area was situated between the Ždánice-Subsilesian sedimentary area and autochthonous Paleogene of platform margin (Nesvačilka and Vranovice submarine canyons). The submarine canyon setting controlled the deposition of organic-rich brown muds during the late Eocene while in the Ždánice-Subsilesian sedimentary area deposition of grey and greenish clays prevailed.

The Oligocene Menilite Formation in Moravia is subdivided from the bottom to top to four members with specific lithology and fossil record (Fig. 2): the Subchert Member (hemipelagic marls and mudstones), Chert Member (menilite cherts and claystones), Dynów Member (nannofossil marlstone) and Šitbořice Member (hemipelagic marls and mudstones). The formation contains many anoxic horizons with abundant skeletal fish remains and sporadic fish otoliths. Locally, in the Bystřice nad Olší area, the Menilite Formation laterally passes to clayey sandstones and pebbly mudstones of submarine slumps described by Menčík et al. (1983) under the informal name "Formation of pebbly mudstones". The mudstones lack the skeletal fish fauna but contain otolith fauna in places.

\section{Material and methods}

The otolith fauna was found at several localities in external nappe units of Western Carpathians in Moravia (Fig. 1). The fossil material from the Subsilesian Unit

\begin{tabular}{|c|c|c|c|c|c|c|c|}
\hline \multicolumn{4}{|r|}{${ }^{*} 1$} & *2 & Pouzdřany Unit & Ždánice Unit & Subsilesian Unit \\
\hline$\Sigma$ & 这 & ๘ & \begin{tabular}{|l|}
$\mathrm{NN} 2$ \\
$\mathrm{NN} 1$ \\
\end{tabular} & M1 & \multirow{4}{*}{ Uherčice Fm. } & \multirow{3}{*}{ Ždánice-Hustopeče Fm. } & \multirow{3}{*}{ Ženklava Fm. } \\
\hline \multirow{5}{*}{ 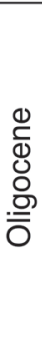 } & 穿 & 离 & NP25 & O6 & & & \\
\hline & $\frac{\pi}{U}$ & & & O5 & & & \\
\hline & \multirow{3}{*}{ 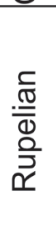 } & \multirow{3}{*}{ 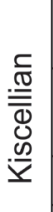 } & \multirow[b]{2}{*}{ NP23 } & $\begin{array}{l}\mathrm{O} 4 \\
\mathrm{O} 3 \\
\end{array}$ & & Šitbořice Mb. & غં Šitbořice Mb. \\
\hline & & & & $\mathrm{O} 2$ & \multirow{2}{*}{ diatomites } & Dynów Mb. & Dynów Mib. \\
\hline & & & NP22 & 01 & & $\begin{array}{l}\text { Chert Mb } \\
\text { Subchert Mb. }\end{array}$ & $\begin{array}{l}\text { Chert Mb } \\
\text { Subchert Mib }\end{array}$ \\
\hline ن山 & $\ddot{0}$ & $\dot{\bar{n}}$ & & E16 & Pouzdřany Fm. & Němčice Fm. Sheshory Mb. & Frýdlant Fm. Sheshory Mb. \\
\hline
\end{tabular}

Figure 2. Oligocene lithostratigraphy of the Pouzdřany, Ždánice and Subsilesian units (after Stráník et al. 1991, modified). Abbreviations: *1 - Martini (1971); *2 - Berggren \& Pearson (2005); E. - Eocene; M. - Miocene; Pr. - Priabonian; Aq. - Aquitanian; P. M. - pebbly mudstones. 
was collected during field works in Bystřice nad Olší during years $1979-84$ by one of the authors (M.B.). Isolated otoliths were obtained from the weathered matrix of pebbly mudstones from the Jatný MB067 and Hluchová MB028 sections by washing. The otolith fauna from clayey sandstone at Hluchová MB029 section was retrieved by the careful splitting of the rock. Since the times of field works the otolith-bearing outcrops at the Hluchová MB028 and MB029 sections were covered by riprap boulders protecting the stream banks against erosion and are not accessible any-more.

The otoliths and other fish remains (teeth, scales) from the Ždánice Unit were collected at surface outcrop of the Dynów Member in Moutnice (R.B.). The otoliths were collected directly from the lamination surface of the silicified marlstones. Further otoliths of the Menilite Formation were obtained from the core of the Křepice- 5 borehole by washing on sieves $0.063-2.0 \mathrm{~mm}$ (R.B.). Borehole section was sampled for otoliths every metre.

The otoliths were examined using a Wild Heerbrugg microscope. Taxonomic notes are ordered after Nelson et al. (2016). All otolith-based species from Subsilesian and Ždánice units are listed and those discussed in "Taxonomic notes" are figured. Following the nomenclatory practice of Lin et al. (2016), the species, that cannot be attributed to a particular modern genus, are coupled with the generic name of the type genus of the family or tribe enclosed in inverted commas (see 'Phosichthys' and 'Diaphus').

All figured specimens are deposited in the collection of types at the Department of Geological Sciences of the Masaryk University in Brno (DGS MU) under collection numbers O279 to O296.

Brief descriptions of sections in the Subsilesian and Ždánice units situated in different parts of Moravia and Silesia are given below:

Hluchová MB028. - The section was situated in the left bank of the Hluchová Brook in Bystřice Village $\left(49^{\circ} 38^{\prime} 44.6^{\prime \prime} \mathrm{N}, 18^{\circ} 44^{\prime} 22.0^{\prime \prime} \mathrm{E}\right)$. It comprises continuous succession from the Sheshory Member to the Subchert Member (Fig. 3). Brown mudstones of the Subchert Member contained 10 to $100 \mathrm{~cm}$ thick horizons and lenses of pebbly mudstones with pebbles of quartz, metamorphic rocks, carbonates, and small macrofauna: bivalves, gastropods, brachiopods, large foraminifera, bryozoans, serpulids, echinoid elements, and rare otoliths. The planktonic foraminifera Dipsidripella danvillensis (H. et W.), Turborotalia ampliapertura (Bolli), Pseudohastigerina micra (Cole), Tenuitella brevispira (Subb.) indicate Oligocene age and reworking from the Eocene. The underlying Sheshory Member consisted of light grey mottled marl with few thin marlstone intercalations. Planktonic foraminifera Turborotalia ampliapertura (Bolli), Catapsydrax howei (B. et B.), and frequent Dipsidripella danvillensis (H. et W.) indicate its late Eocene age.

Hluchová MB029. - About $50 \mathrm{~m}$ upstream from the MB028, small outcrop was exposed in the left bank of Hluchová Brook (49 38 45.6" N, $18^{\circ} 44^{\prime} 24.0^{\prime \prime}$ E). Beige nannofossil marlstone (Dynów Marlstone) enclosed the slump body of brown-grey sandy mudstone to clayey sandstone (Fig. 3). The sandy mudstone displayed convolute lamination, slump folds, and pebble admixture. The marlstone contained mass occurrence of nannofossil Reticulofenestra ornata, isolated fish bones and gill spines of Keasius parvus (Leriche). The sandy mudstone contained small molluse macrofauna Thyasira sp., Cuspidaria sp., Solemya bachmayeri Ctyroky, Retusa sp., Roxania sp., Limatula sp., rare hexacorals and tubes of Ditrupa sp. Planktonic foraminifer assemblage with Globigerina praebulloides (Blow), Globoturborotalita ouachitaensis (H. et W.), Turborotalia ampliapertura (Bolli), Tenuitella brevispira (Subb.) and Pseudohastigerina naguewichiensis (Mjat.) indicates the O1 Zone sensu Berggren \& Pearson (2005) that may be correlated with the lower Kiscellian.

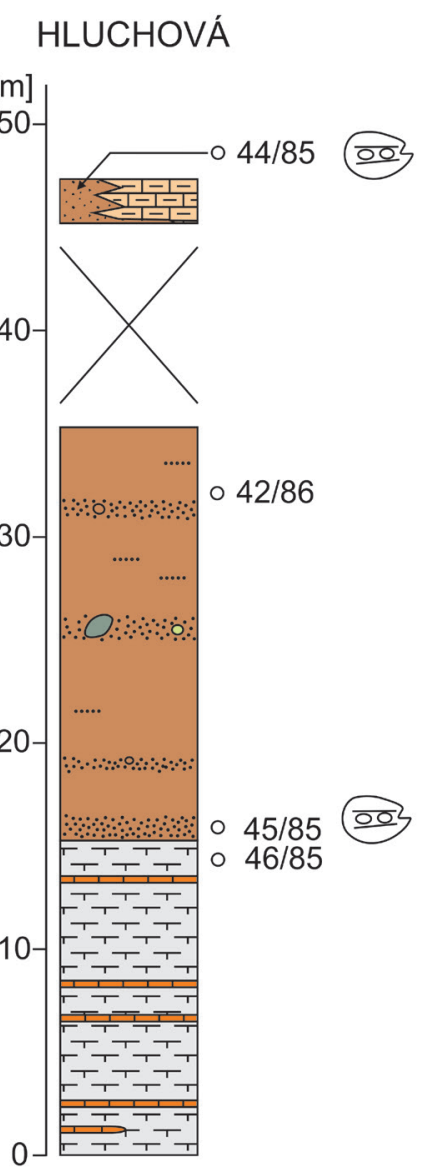

Figure 3. Lithology and stratigraphy of the Hluchová MB028 and MB029 sections with indicated finds of otolith fauna and micropalaeontological samples. 
Jatný MB067. - The section is situated in the deep gully of

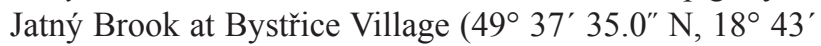
06.9" E). Well exposed continuous section of strata (Fig. 4) was informally named "Formation of pebbly mudstones" by Menčík et al. (1983). The formation rests by erosional base on early Eocene mudstone-sandstone turbidites of the Frýdlant Formation. The basal member consists of light-grey sandstone turbidites. They are overlaid with slump body of brown-grey clayey sandstone. The highest part consists of brown pebbly mudstone with submarine slump and landslide structures. The mudstone contains detritic layers and lenses (like at MB028) and blocks of exotic rocks up to $2 \mathrm{~m}$ in diameter (metamorphics, marlstones, claystones, nummulitic limestones, sandstones, coal etc.). The detritic layers contain small macrofauna: molluscs Propeamusium cf. fallax (Korob.), Lima sp., Barbatia sp., Cardita sp., Ostrea sp., Chlamys sp., Astarte sp., Dentalium sp., gastropods, nummulits, large Bathysiphon tubes, bryozoans, brachiopods, serpulids, echinoid and crinoid elements, and rare otoliths.

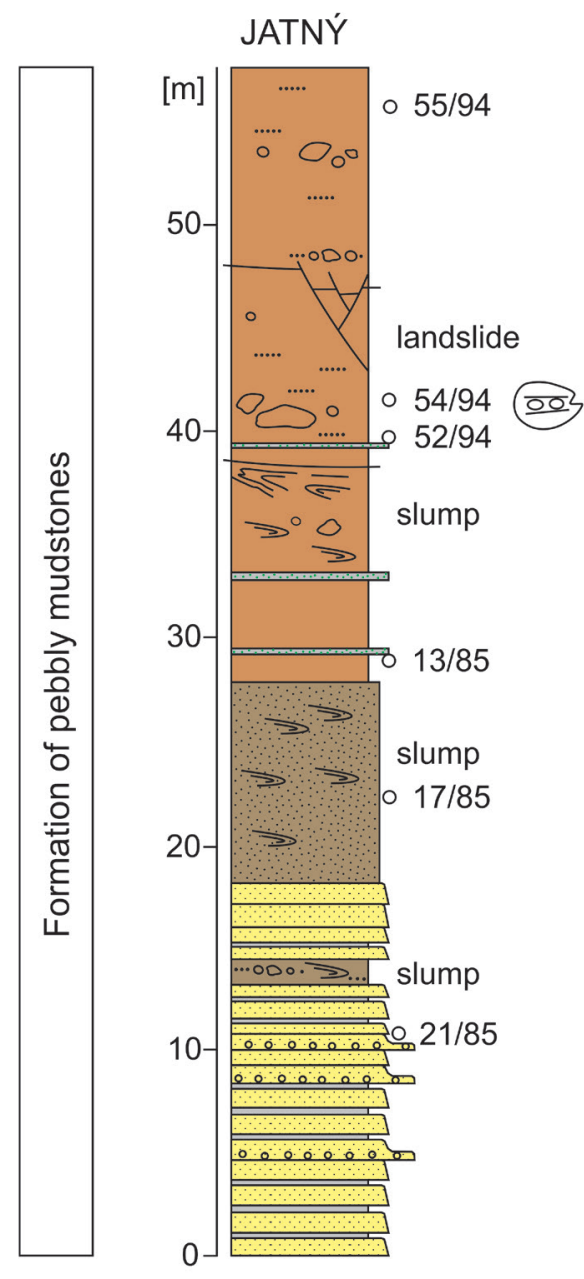

Figure 4. Lithology and stratigraphy of the Jatný MB067 section with indicated finds of otolith fauna and micropalaeontological samples.
Planktonic foraminifers Subbotina patagonica T. et K., Acarinina bullbrooki (Bolli), A. pseudotopilensis Subb., A. pseudodubia (Bandy), Dipsidripella danvillensis (H. et W.), Turborotalia ampliapertura (Bolli) from the mudstones evidence reworking from different levels of the Eocene.

Moutnice. - In an abandoned small quarry in the fields southeast of Moutnice Village $\left(49^{\circ} 02^{\prime} 42.7^{\prime \prime} \mathrm{N}, 16^{\circ} 44^{\prime}\right.$ 45.7" E), the Dynów Member was exposed. It consists of brownish and whitish partly silicified marlstone with fish bones thrusted over light grey silicified claystone (Cicha 1968). Otoliths were collected from the marlstone in the $70 \mathrm{~s}$ of the $20^{\text {th }}$ century (Brzobohatý 1981). The marlstone contained mass occurrence of nannofossil Reticulofenestra ornata - acme correlated with the NP23 Zone (Krhovský 1981). The quarry was later filled and returned under agricultural cultivation.

Křepice-5. - Fully cored borehole was situated southwest of Křepice Village ( $\left.48^{\circ} 59^{\prime} 39.8^{\prime \prime} \mathrm{N}, 16^{\circ} 42^{\prime} 31.5^{\prime \prime} \mathrm{E}\right)$. It was drilled in 1981, penetrated complete sequence of the Menilite Formation and reached the Němčice Formation with final depth $200 \mathrm{~m}$ (Stráník et al. 1981, Švábenická et al. 2007). The record from the bottom to the top of the borehole is as follows:

200.0-159.3 m: Němčice Formation (green-grey noncalcareous clays),

199.3-114.2 m: Sheshory Member (so-called "Globigerina marl" facies with Tenuitella liverovskae, Chiloguembelina sp., Reticulofenestra umbilica, Dictyococcites bisectus, etc.),

114.2-112.3 m: Subchert Member (grey-brown calcareous claystones),

112.3-106.7 m: Chert Member (menilite cherts and greybrown silicified claystones),

106.7-95.1 m: Dynów Member (light brown-grey marlstone),

95.1-25.3 m: Šitbořice Member (light grey calcareous-noncalcareous claystone with Reticulofenestra ornata, $\mathrm{Cyc}$ licargolithus abisectus, Pontosphaera pygmaea, etc.),

25.3-1.0 m: Ždánice-Hustopeče Formation (grey clays, siltstones, and sandstones).

Abundant otoliths were retrieved from the Sheshory Member, sporadic otoliths from the Dynów and Šitbořice members (Brzobohatý 1981).

\section{Results}

Otoliths obtained from the Paleogene of the Subsilesian Unit in Bystřice nad Olší are recrystallized and more or 
less corroded and/or worn. Higher abundance and better preservation of otoliths were encountered in sandy slump body within the Dynów Member at the Hluchová MB029 section. The "Formation of pebbly mudstones" at the Jatný MB067 section yielded rather scarce and poorly preserved otoliths. In the pebbly mudstones of the Hluchová MB028 section, a single corroded otolith of Scopelarchus sp. was found.

The recovery and preservation of otolith assemblages from easily disintegrating rocks of the Ždánice Unit were much better.

The otoliths of the Subsilesian Unit revealed the presence of seven nominal species, as well as five taxa identified in open nomenclature only (Tab. 1). Myctophids dominate the assemblage. Their otoliths are mostly eroded and hardly determinable at the species level. Three nominal species could be distinguished: Oligophus moravicus (Pauca), 'Diaphus' alcoholicus Brz. \& Nolf, and 'D.' cf. excavatus (Šulc). First two mentioned taxa are proved by well-preserved otoliths. The third one is based on single eroded otolith and could belong to the Priabonian species ' $D$.' excavatus.

Valenciennellus brzobohatyi Sterbaut, Melanonus triangulus (Robba) and 'Phosichthys' triquetrus (Brzobohatý) represent other fossil species with well-preserved otoliths.
Seven taxa (four nominal) were documented in the Ždánice Unit (Tab. 1). Besides the taxa mentioned above, two other nominal species: Bregmaceros catulus (Schubert) from the Sheshory Member and Coryphaenoides aff. guentheri (Vaillant) from the Dynów Member were recorded.

\section{Taxonomic notes}

Family ?Synaphobranchidae gen. et sp. indet. Figures 5L1, L2; 6L

The only one adult specimen with kidney-shaped morphology from the Jatný MB067 could be generally compared with otoliths of this family (e.g. Smale et al. 1995, pl. 3, figs a-c; Nolf 2013, pl. 18) but its sulcus is poorly preserved. No otolith-based fossil record of the family Synaphobranchidae is known so far.

\section{Glossanodon sp.}

Figures 5N1, N2, O; 6N

Two slightly worn specimens were found in the Dynów Marlstone at the Moutnice locality. They show a ju-

Table 1. Otolith based fish taxa represented in the Ždánice Unit (Brzobohatý 1981, revised) and Subsilesian Unit. Abbreviations: PM - pebbly mudstones; Sh - Sheshory Mb.; D - Dynów Mb.; Si - Šitbořice Mb.; * - extant genera living out of Mediterranean waters; \# - extinct genera.

\begin{tabular}{|c|c|c|c|c|c|c|c|c|}
\hline & & \multicolumn{3}{|c|}{ Subsilesian Unit } & \multicolumn{4}{|c|}{ Ždánice Unit } \\
\hline & & $\begin{array}{l}\widehat{\delta} \\
\dot{0} \\
\dot{\Sigma}\end{array}$ & $\begin{array}{l}\infty \\
\stackrel{0}{ } \\
\stackrel{\leftrightarrow}{\Sigma}\end{array}$ & 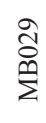 & \multicolumn{3}{|c|}{ Křepice 5} & 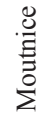 \\
\hline & & $\mathrm{PM}$ & PM & $\mathrm{D}$ & Sh & $\mathrm{D}$ & $\mathrm{Si}$ & $\mathrm{D}$ \\
\hline Synaphobranchidae & * ?Synaphobranchidae gen. et sp. indet. & $\mathrm{x}$ & & & & & & \\
\hline Argentinidae & Glossanodon sp. & & & & & & & $\mathrm{x}$ \\
\hline Alepocephalidae & * Xenodermichthys senesi N. \& B. & cf. & & & & & & \\
\hline Sternoptychidae & *Valenciennellus brzobohatyi $\mathrm{S}$. & & & & $\mathrm{x}$ & & & \\
\hline \multirow[t]{2}{*}{ Phosichthyidae } & Vinciguerria sp. & & & $\mathrm{x}$ & & & & $\mathrm{x}$ \\
\hline & 'Phosichthys' triquetrus (B.) & & & $\mathrm{x}$ & & & & \\
\hline Scopelarchidae & * Scopelarchus sp. & $\mathrm{x}$ & $\mathrm{x}$ & & & & & \\
\hline \multirow[t]{4}{*}{ Myctophidae } & 'Diaphus' alcoholicus B. \& N. & & & $\mathrm{x}$ & & & & \\
\hline & 'Diaphus' cf. excavatus (S.) & $\mathrm{x}$ & & & & & & \\
\hline & 'Diaphus' sp. & $\mathrm{x}$ & & & & & & \\
\hline & \# Oligophus moravicus (P.) & & & $\mathrm{x}$ & $\mathrm{x}$ & $\mathrm{x}$ & $\mathrm{x}$ & \\
\hline Bregmacerotidae & Bregmaceros catulus (S.) & & & & $\mathrm{x}$ & & & \\
\hline Melanonidae & Melanonus triangulus (R.) & & & $\mathrm{x}$ & & & & \\
\hline \multirow[t]{2}{*}{ Merlucciidae } & \# Palaeogadus cf. intergerinus D. & & & $\mathrm{x}$ & & & & \\
\hline & \# Palaeogadus sp. & & & & & $\mathrm{x}$ & & $\mathrm{x}$ \\
\hline \multirow[t]{2}{*}{ Macrouridae } & Coryphaenoides aff. guentheri (V.) & & & & & & & $\mathrm{x}$ \\
\hline & Coryphaenoides sp. & & & $\mathrm{x}$ & & & & \\
\hline
\end{tabular}


venile morphology close to argentines. They seem to correspond with juvenile otoliths of the present-day species Glossanodon leioglossus (Valenciennes, 1848) see Tuset et al. (2008, pl. 17, fig. c1). Otoliths of $G$. pygmaeus Cohen, 1958 show also a similarity in dorsal and ventral rim (see Nolf 2004, pl. 4, fig. 10). The similar and well-known otoliths of the Oligocene-Miocene species Argentina parvula (Koken, 1891) differ from our specimens in the presence of a small antirostrum, a perspicuous medioventral angle, and a slightly concave anteroventral margin (e.g. Nolf 1977, Schwarzhans 1994). After Schwarzhans $(1994,2010)$ this species represents a monospecific extinct genus Pseudargentina Schw. belonging to the sternoptychids. It is noticeable, that skeletons of the extinct Glossanodon musceli (Pauca, 1929) occur very often in the lower and middle Oligocene of the studied area (e.g. Gregorová 1997, Kotlarczyk et al. 2006, Přikryl 2013).

\section{Xenodermichthys cf. senesi Nolf \& Brzobohatý, 1994}

Figures 5H1, H2; 6H

The only specimen from pebbly mudstones at the Jatný MB067 section is poorly preserved, but its rhomboidal outline and well-marked rostrum show more similarity to the otoliths of the upper Oligocene species $X$. senesi than to those of the extant and worldwide $X$. copei (Gill, 1884) - see Nolf \& Brzobohatý (1994, pl. 2). It differs also from $X$. aff. copei from the upper Burdigalian of the Piedmont Basin (Nolf \& Brzobohatý 2004) or from the Lower Badenian (= Langhian) of the Central Paratethys (Brzobohatý 1986; as 'Searsia' kotthausi) by more konvex dorsal rim, longer postdorsal projection, and clearly convex outer face. Much more differences could be found in the specimen described as $X$. sp. from the Mediterranean Wurmian (Pleistocene; Girone et al. 2006). $X$. senesi is known from the upper Kiscellian (NP 24) of the Central Paratethys, from the Chattian (NP 24-25) of the Aquitaine Basin (Nolf \& Brzobohatý 1994, 2002), and from the Tortonian of the Mediterranean (Lin et al. 2017). The uncertain occurrence in the Langhian of the Aquitaine Basin is based on a single eroded specimen (Nolf \& Brzobohatý 2002).
Valenciennellus brzobohatyi Steurbaut, 1982

Figures 5B1, B2, B3; 6B

The species possesses a wide stratigraphic range from the upper Eocene to the upper Oligocene and occurs in Aquitaine and Mediterranean basins. In the Central Paratethys, the species has been recorded in the Pouzdřany Marl and Kiscell Clay (Brzobohatý \& Krhovský 1998, Nolf \& Brzobohatý 1994) and newly also in the Sheshory and Dynów members.

\section{'Phosichthys' triquetrus (Brzobohatý, 1967) \\ Figures 5A1, A2; 6A}

The only adult and very well preserved specimen from Dynów Marlstone at Hluchová MB029 Section contributes to our knowledge of the otolith morphology of the species. Its anterior part shows a distinct and sharp rostrum, a slightly shorter antirostrum, and a relatively deep excisura in comparison with adult otoliths of the type series. They have a mostly broken or eroded anterior part (Brzobohatý 1967, pl. 1, fig. 3). Systematic position of the species among lightfishes remains uncertain. This species occurs rarely in the lower Oligocene NP21 to lower NP22 zones of the Pouzdřany Unit (Brzobohatý \& Krhovský 1998). Some corroded otoliths from the Ranzano Formation of Italy (Vigoponzo, lower Oligocene) figured as Phosichthys sp. by Nolf \& Steurbaut (2004, pl. 2, fig 10, non fig. 9) could be conspecific with the specimens from Pouzdřany and Hluchová.

\section{Scopelarchus sp.}

Figures 5M1, M2; 6M

Two juvenile eroded specimens from the Subchert Member at the Hluchová Section and pebbly mudstones at the Jatný MB067 Section show enough morphological evidence to attribute them to the genus Scopelarchus. The single fossil nominal species - S. nolf Steurbaut, 1982 - is documented in the European Oligocene and Miocene. The juvenile otoliths from the Pouzdřany Marl described as $S$. moravicus Brzobohatý, 1982 could be conspecific (Nolf \& Brzobohatý 1994). Additional and better-preserved

Figure 5. Otoliths from the Subsilesian and Ždánice units. • A1, 2 - 'Phosichthys' triquetrus (Brzobohatý); Le, Hluchová MB029 (DGS MU: O279). B1, 2, 3 - Valenciennellus brzobohatyi Steurbaut; Le, Křepice-5: 115.7 m (DGS MU: O280). • C1, 2 - 'Diaphus' alcoholicus Brzobohatý \& Nolf; Le, Hluchová MB029 (DGS MU: O281). • D1, 2 - Oligophus moravicus (Pauca); Le, Hluchová MB029 (DGS MU: O282). E1, 2 - Vinciguerria sp., Le, Moutnice (DGS MU: O283)••F - 'Diaphus' sp.; Ri, Jatný MB067 (DGS MU: O284). • G1, 2 - 'Diaphus' cf. excavatus (Šulc); Ri, Jatný MB067 (DGS MU: O296). • H1, 2 - Xenodermichthys cf. senesi Nolf \& Brzobohatý; Ri, Jatný MB067 (DGS MU: O285). I1, 2, J - Melanonus triangulus (Robba); I = Le, J = Ri, Hluchová MB029 (DGS MU: O286-O287). K1, 2 - Coryphaenoides aff. guentheri (Vaillant); Le, Moutnice (DGS MU: O288). L1, $2-$ ?Synaphobranchidae gen. et sp. indet.; Le, Jatný MB067 (DGS MU: O289). M1, 2 - Scopelarchus sp.; Ri, Jatný MB067 (DGS MU: O290). N1, 2, O - Glossanodon sp.; Le, Moutnice (DGS MU: O291-O292). P1, 2 - Palaeogadus cf. intergerinus Daniltshenko; Le, Hluchová MB029 (DGS MU: O293). • R1, 2 - Bregmaceros catulus (Schubert); Ri, Křepice-5: 115.7 m (DGS MU: O294). S - Coryphaenoides sp.; Le, Hluchová MB029 (DGS MU: O295). Abbreviations: 1 - ventral; 2 - inner (mesial); 3 - posterior view; Le - left otolith; Ri - right otolith. 


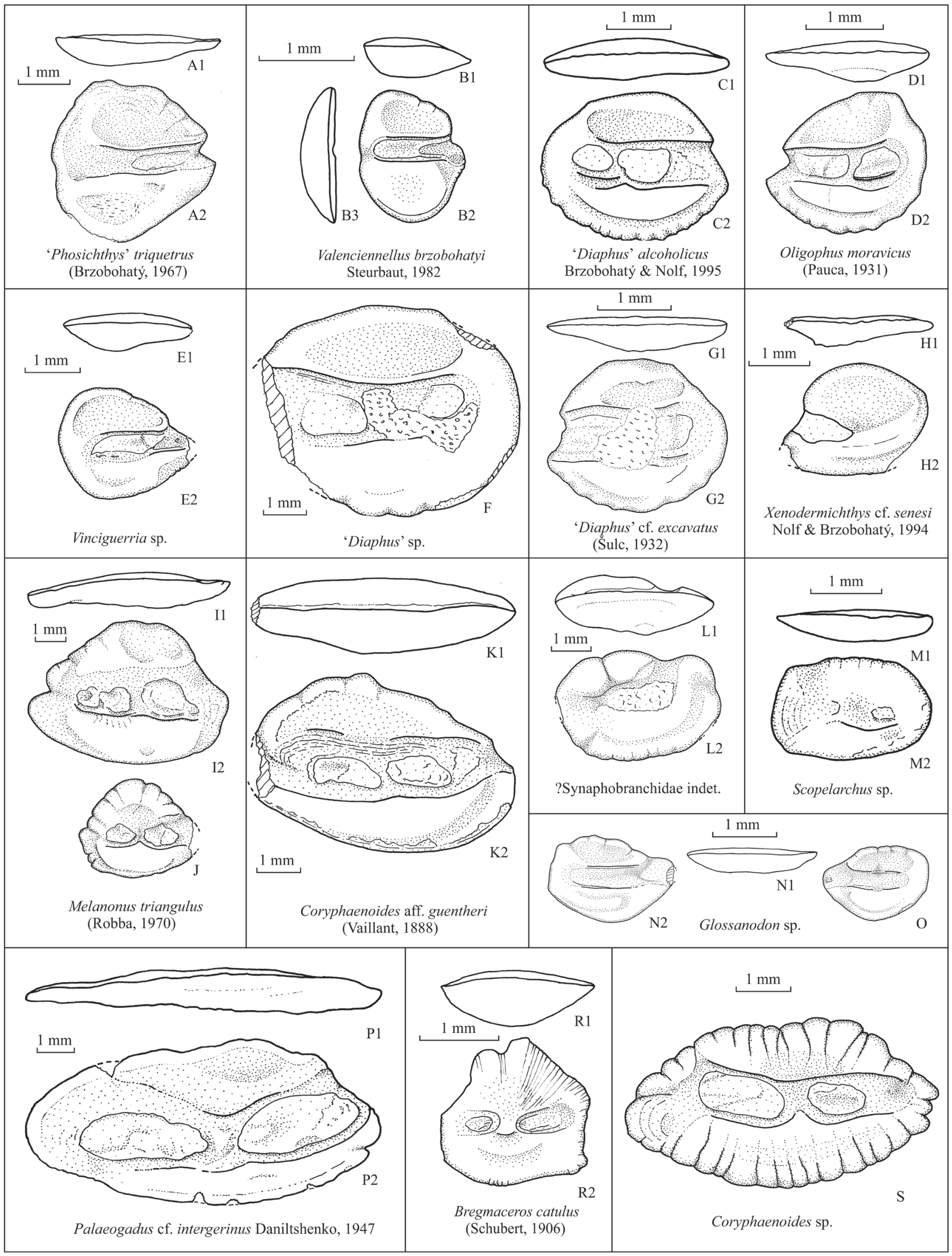


material from the Outer Flysch Carpathians is needed for a more precise comparison.

\section{Oligophus moravicus (Pauca, 1931)}

Figures 5D1, D2; 6D

Oligophus moravicus presents a very rare case of species fully documented by skeletons, isolated otoliths, and skeletons with otoliths in situ facilitating a correlation based on different types of fossils. The new in situ finds (Přikryl et al. 2017) document that the skeleton-based species O. moravicus represents a senior synonym of the otolithbased 'Diaphus' longirostris (Brzobohatý). These otoliths are the most numerous species of the Sheshory, Dynów, and Šitboríce members in the Ždánice Unit and of the Dynów Mb. at the Hluchová MB029 section (Subsilesian Unit). Oligophus moravicus (Pauca) is a typical component of mesopelagic assemblages in the Oligocene deposits of the Aquitaine, Mediterranean, and Paratethys basins (e.g. Brzobohatý \& Nolf 1995, Nolf \& Brzobohatý 1996).

\section{'Diaphus' alcoholicus Brzobohatý \& Nolf, 1995} Figures 5C1, C2; 6C

One otolith from the Dynów Marl of the Hluchová MB029 Section represents this species very well. According to Prrikryl et al. (2017), the species very likely belongs to the genus Eomyctophum. Sporadic occurrence of the species contrasts strongly with its abundance in the lower Oligocene sediments of the Pouzdřany Unit (Brzobohatý 1967, Brzobohatý \& Krhovský 1998). It is also a typical component of Oligocene mesopelagic assemblages of the Aquitaine, Mediterranean, and Paratethys basins (e.g. Brzobohatý \& Nolf 1995, Nolf \& Brzobohatý 1996).

\section{'Diaphus' cf. excavatus (Šulc, 1932)}

Figures 5G1, G2; 6G

'Diaphus' excavatus is the typical Eocene species known from the Lutetian to Priabonian of the Aquitaine Basin and Mediterranean realm (Nolf 1988, Nolf \& Girone 2008, Lin et al. 2016). The Jatný specimen slightly differs from the holotype (Šulc 1932, pl. 3, fig. 4) by having a more prominent rostral portion. Much more material is needed for precise systematic conclusion.

\section{'Diaphus' sp.}

Figures $5 \mathrm{~F}, 6 \mathrm{~F}$

The single giant specimen denominated as 'Diaphus' sp., much longer than $5.5 \mathrm{~mm}$, lacks the anterior portion. It represents the so-far biggest myctophid otolith known from the Oligocene of Paratethys. Its dimensions and relatively well preserved posterior portion resemble adult otoliths of ' $D$.' molossus Nolf \& Steurbaut (1988, pl. 2, fig. 8) from the Mediterranean lower Oligocene. Much more material is needed to decide about the systematic position of our specimen. Although dimensions of otoliths must not be related to dimensions of a fish body, it is noticeable, that fragments of extraordinarily large skeletons are also informally described as "Myctophidae, typus Giant II" from several Polish Oligocene sections (Kotlarczyk et al. 2006, pl. 19b).

\section{Bregmaceros catulus (Schubert, 1908) \\ Figures 5R1, R2; 6R}

Bregmaceros catulus is a lower Oligocene Paratethyan species known from the Pouzdřany Unit (localities "Pouzdřany - Wine cellars" and "Pouzdřany - U Šípku") and from the Sheshory Member of the Ždánice Unit (Křepice-5 borehole). It differs from the otoliths of $B$. albyi (Sauvage, 1880) by longer form (L:H >1.0) and higher position of the postdorsal projection at adult specimens (comp. Brzobohatý 1967, pl. 1, figs. 10, 12-15; Nolf 2013, pl. 86; Přikryl et al. 2016, text-fig. 6).

\section{Melanonus triangulus (Robba, 1970)}

Figures 5I1, I2, J; 6I, J

Two very well preserved specimens from the Dynów Member at the Hluchová MB029 Section were available. The adult one (Fig. 5I1) is very close to the holotype (Robba 1970, pl. 11, fig. 7) and the smaller one (Fig. $5 \mathrm{~J})$ is more undulated on the margins. These otoliths occur relatively rarely in the lower Oligocene to middle Miocene of Paratethys and in the Mediterranean from the lower Oligocene (as M. gabbai, NP 21, Nolf \& Steurbaut 1988) to upper Miocene.

\section{Palaeogadus cf. intergerinus Daniltshenko, 1947}

Figures 5P1, P2; 6P

The single adult otolith (longer than $10.0 \mathrm{~mm}$ ) from the Dynów Member at the Hluchová Section with more or less eroded margins corresponds fairly well with the morphology of adult specimens of the genus. Its shape and two homogenous collicula seem to be comparable with $P$. intergerinus. This species is originally based on skeleton from the early Oligocene of Eastern Paratethys. Fedotov (1976, text-fig. 5v, g) figured besides one relatively young specimen (length about $6.5 \mathrm{~cm}$ ) also wellpreserved otolith. Much more material from both regions is needed to decide about a systematic status of our specimen. Skeletons of $P$. intergerinus are also described from the Rupelian of Romanian South Carpathians (Ciobanu 1977) and the Chattian of Polish Carpathians (Kotlarczyk et al. 2006). 


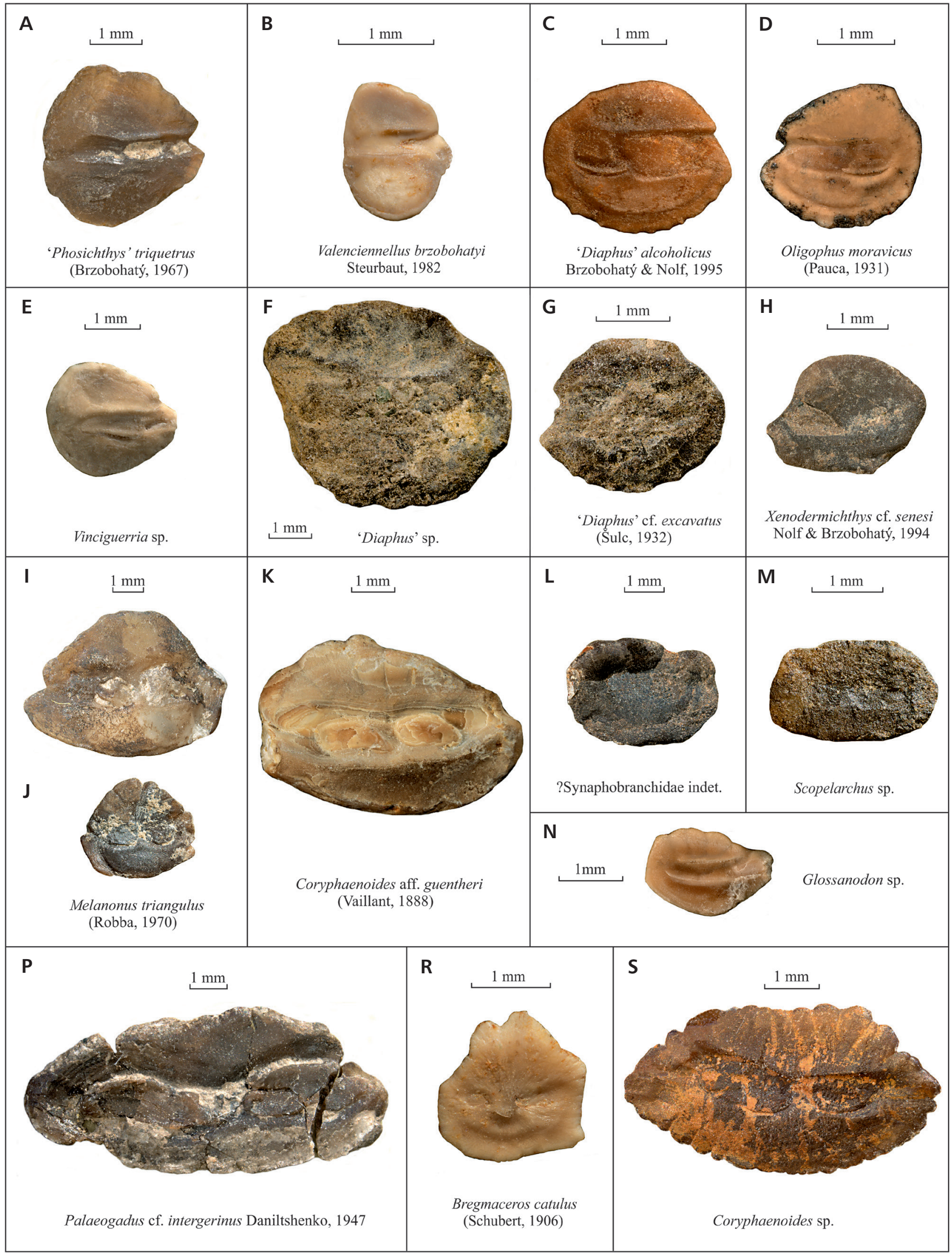

Figure 6. Otoliths from the Subsilesian and Ždánice units. - Photographs of the inner (mesial view). For explanations see Fig. 5. 
There are two other otolith-based Palaeogadus species known from the West Carpathian Flysch Belt. The first oneP. emarginatus (Koken, 1884) - are relatively abundant in the Pouzdřany Marl (NP21/NP22) at the locality "Pouzdřany - wine cellars" (Brzobohatý 1967). Its ostium and ostial colliculum are markedly shorter than the caudal ones in comparison with the Hluchová specimen. Another Palaeogadus species from the Menilite Formation of Czech Republic - "Nemopteryx moravicus" Weiler, 1935 (p. 37, text-fig. 7) - represents a doubtful or rejected species because of strongly worn holotype (Nolf 1985, 2013). Additional fragments and worn specimens, similar to figured specimen, were found in the same stratigraphic level of the Hluchová Section.

\section{Coryphaenoides aff. guentheri (Vaillant, 1888)}

Figures 5K1, K2; 6K

The single specimen from the Dynów Member at Moutnice lacks the posterior projection. Its morphology is comparable with otoliths of the same size of the presentday species $C$. guentheri figured by Tuset et al. (2008, pl. 25 , fig. b2). They seem to differ only in the more prominent predorsal portion and antirostrum. Pleistocene otoliths from the Mediterranean figured by Girone (2003, pl. 1, figs $6 \mathrm{a}-\mathrm{c}$ ) as $C$. cf. guentheri show a juvenile morphology that differs in the shape and the more undulated outline. Certain similarity could be found with otoliths of another Atlantic species, C. zaniophorus (Vaillant, 1888). Otoliths of this species were figured by Nolf \& Steurbaut as $C$. colon $(1983$, pl. 5, figs 7,8$)$ but they seem to differ in a more prominent posterior projection.

\section{Coryphaenoides sp.}

Figures 5S, 6S

A single well-preserved otolith from the Dynów Member at the Hluchová Section is fixed in the rock and its outer face is not visible. The insufficient material does not allow a more precise determination.

\section{Discussion}

Two deep-water oceanic fish faunas were identified in the Paleogene of the Subsilesian Unit: 1) "Hluchová fauna" found in the slump body within the Dynów Member at the Hluchová MB029 section, comprising seven taxa indicative of lower slope environment. 2) "Jatný fauna" found in pebbly mudstones of the Jatný 067 section seems to be shallower and indicative of upper slope environment.

Palaeobathymetric interpretation of the "Hluchová fauna" is inferred from bathymetrical preferences of modern representatives of recorded genera. In the recent waters, the genus Valenciennellus is represented by two bathypelagic non-migratory species living usually between 200 and $400 \mathrm{~m}$. Lampanyctins are diversified in presentday seas what can be demonstrated on diaphids with 78 species. The Lampanyctins belong to oceanodromous, mesopelagic-bathypelagic (rarely bathydemersal) fishes with daily vertical nocturnal feeding migrations into the epipelagic zone. The same could be applied to fishes of the family Phosichthyidae but with an inclination to the deeper mesopelagic and bathypelagic depths. Two present day species of the genus Melanonus belong to typical oceanodromous and bathypelagic fishes with a very wide bathymetric range $(0-3000 \mathrm{~m})$. They are missing in the present day Mediterranean including world-widely distributed M. zugmayeri Norman. Melanonus gracilis Guenther, a typical South Atlantic species, usually prefers depths between 600-1100 m. Although Coryphaenoides species may occur as shallow as $300 \mathrm{~m}$ and very exceptionally above, they are first of all characteristic for bathyal environment, usually below $1000 \mathrm{~m}$ (Froese \& Pauly 2018).

Accompanying mollusc and foraminifers represented by small plankton and calcareous benthos indicate outer shelf and upper slope hypoxic habitats. It is anyhow necessary to emphasize that both benthic macrofauna and foraminifer microfauna are found solely in slump body within the Dynów Marlstone and are completely reworked. The marlstone itself is barren of foraminifers and molluscs on the wide regional scale (Carpathians). The otolith fauna may be considered as an autochthonous component of pseudoassemblage. The lack of otoliths in the surrounding Dynów Marlstone seems to have taphonomic causes. The otoliths in the slump sandy mudstone are recrystallized and can be easily retrieved from the rock.

The "Hluchová fauna" seems to be very similar to the deep-water component of the otolith fauna from the Pouzdřany Marl (Tab. 2). The stratigraphic similarity is emphasized by the presence of Valenciennellus brzobohatyi, 'Phosichthys' triquetrus, Oligophus moravicus, 'Diaphus' alcoholicus, and Melanonus triangulus, which has been documented at different localities of the Pouzdřany Marl (NP21-22). However, the Pouzdřany otolith assemblages are more diversified (43 taxa) and contain also otoliths of the neritic fishes (Brzobohatý \& Krhovský 1998). This comparison is in agreement with the revised ecostratigraphy of the Polish Outer Carpathian units and the IPM (Ichthyofauna, Paleogene, Menilite) Zones based on fish skeletons (Kotlarczyk et al. 2006). The IPM 1 Zone with dominant meso-bathypelagic fishes includes the Jamna Dolna, Kotów and Dynów members representing the NP22 to lower NP23 zonal interval.

The "Hluchová otolith fauna" (7 genera) and otolith fauna of the Dynów Marlstone in the Ždánice Unit (5 genera) are little known in comparison with the long-time 
Figure 7. Palaeobathymetry of the Teleostean genera from the Dynów Marlstone of the ŽdániceSubsilesian Unit in Moravia.

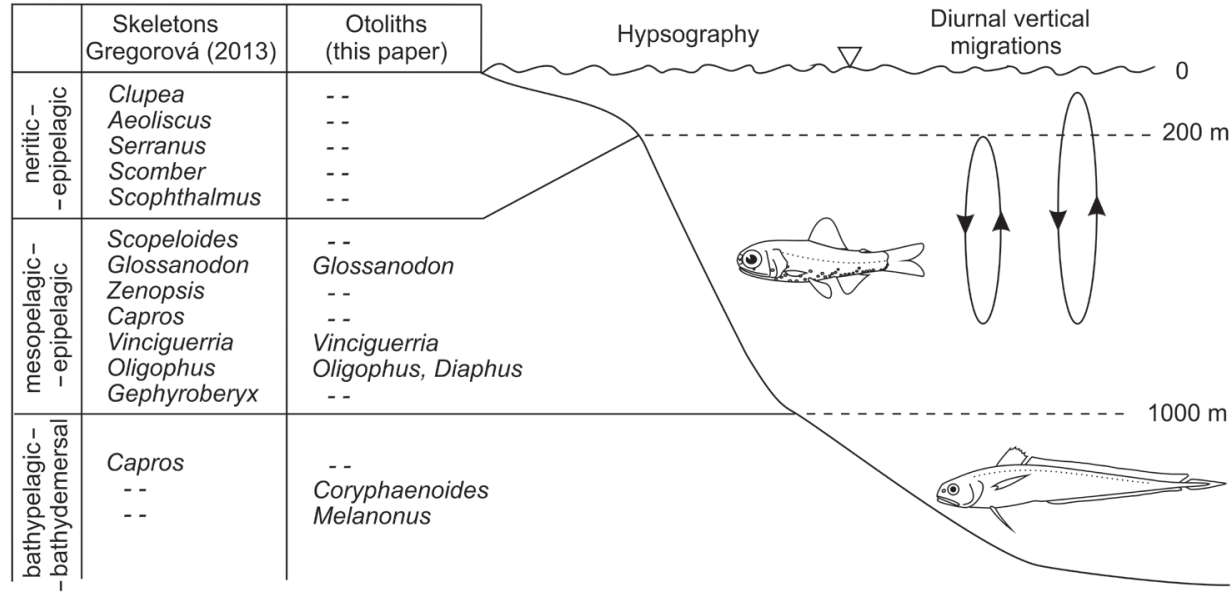

studied skeleton-based assemblages comprising 18 genera (e.g. Gregorová 2013, Přikryl \& Carnevale 2017). The otoliths belong to solely oceanic and deep-dwelling fishes: Glossanodon, Vinciguerria, myctophids, Melanonus, Coryphaenoides, with the exceptions of the extinct genus Palaeogadus. Shallow water taxa-e.g. Clupea, Aeoliscus, Serranus, Scomber, Scophthalmus (Gregorová 2013) - are missing (Fig. 7). It is worthy of note, that skeletal remnants of Vinciguerria, Glossanodon, and myctophids are the most frequent fossils in this stratigraphic level, whereas skeletons of genera Melanonus and Coryphaenoides were not encountered so far. Melanonids have an exclusively otolith-based fossil record (Nolf 2013).

The "Jatný fauna" contains, besides myctophids, juvenile otoliths of two oceanodromous and bathypelagic genera: Xenodermichthys and Scopelarchus. Fishes of the first named genus, like $X$. copei, live usually near continental slope between $100-1230 \mathrm{~m}$. Larvae and juveniles of Scopelarchus (pearleyes) inhabit usually the upper $100 \mathrm{~m}$ depths. Adult Scopelarchus live at depths of the continental slope, S. guentheri even around 4000 metres. Cutthroat eels (Synaphobranchidae) are inhabitants of the continental slope and bathyal environments, but exceptionally in the deep neritic zone.

Pebbly mudstone from the Jatný section contains macrofauna from from shallow water (coralline algae, miliolids, brachiopods Lacazella) to shelf edge/upper slope (sponges, bamboo corals, etc.). Again, as in the case of "Hluchová fauna", the macrofauna and a large part of microfauna are reworked. Large tubular agglutinated foraminifers Bathysiphon sp. in some horizons of the mudstones indicate bathyal zone and seem to be autochthonous. A mixing of foraminifer fauna from different levels of the Eocene raises the question whether the "Jatný otolith fauna" is autochthonous.

Both otolith associations indicate the presence of a relatively unified deep-water oceanic fish fauna in the Oligocene of the Ždánice and Subsilesian units. This fish fauna has a more open oceanic character then the extant fauna of the Mediterranean. Such fauna inhabited wider Mediterranean area since the lower Oligocene until the end of the Pliocene (e.g. Nolf \& Brzobohatý 1994). It comprised a mixture of taxa with a present day Atlantic and Indo-Pacific distribution (Nolf \& Steurbaut 2004). This aspect is also supported by the composition of the Ždánice-Subsilesian assemblages (Tab. 2). Only four genera (Glossanodon, Vinciguerria, Diaphus, and Coryphaenoides) are still living in the Mediterranean Sea. The other seven taxa (Synaphobranchidae, Xenodermichthys, Valenciennellus, Scopelarchus, Bregmaceros, and Melanonus) inhabit the Atlantic and Indo-Pacific realms. These assemblages also show an appreciable similarity with the Lower Oligocene otolith fauna of the Ranzano Formation of the Liguro-Piedmonte Basin, Northern Apennines. Ranzano fauna is, anyhow, more diversified and abundant (Nolf \& Steurbaut 2004).

Relatively wide stratigraphic ranges of fish otoliths provide limited utility in the stratigraphic interpretation. The similarity of the "Hluchová fauna" with a deep-water component of the Pouzdrany Marl and the presence of the 'Phosichthys' triquetrus speak for the lower Oligocene age. Scarce and poorly preserved "Jatný fauna" does not allow any stratigraphic conclusions but its similarity to early Oligocene otolith faunas is apparent. Calcareous nannofossils and planktonic foraminifers allow a more precise stratigraphical assignment of the studied strata (see description of studied sections above). The acme of nannofossil Reticulofenestra ornata in the Dynów Marlstone at the Hluchová MB029 is widely correlated across the Paratethyan Oligocene and assigned to the lower part of the NP23 Zone (e.g. Švábenická et al. 2007). Planktonic foraminifers from otolith-bearing slump body evidence the $\mathrm{O} 1$ Zone that can be correlated with the upper part of the NP21 to NP22 zones according to Berggren \& Pearson (2005). The otolith-bearing pebbly 


\begin{tabular}{|c|c|c|c|c|}
\hline & \multicolumn{3}{|c|}{ Central Paratethys } & \multirow{2}{*}{$\begin{array}{c}\text { Mediterranean } \\
\text { Liguro-Piemonte } \\
\text { Basin }\end{array}$} \\
\hline species & $\begin{array}{c}\text { Pouzdřany } \\
\text { Unit }\end{array}$ & $\begin{array}{c}\text { Ždánice- } \\
\text { Subsilesian } \\
\text { Unit }\end{array}$ & $\begin{array}{c}\text { Pannonian } \\
\text { Basin }\end{array}$ & \\
\hline Xenodermichthys senesi & - & ?PM & K & - \\
\hline Valenciennellus brzobohatyi & $\mathrm{P}$ & Sh, D & $\mathrm{K}$ & $\mathrm{R}$ \\
\hline 'Phosichthys' triquetrus & $\mathrm{P}$ & $\mathrm{D}$ & - & $?$ \\
\hline 'Diaphus' alcoholicus & $\mathrm{P}$ & $\mathrm{D}$ & - & $\mathrm{R}$ \\
\hline 'Diaphus' cf. excavatus & - & PM & - & - \\
\hline Oligophus moravicus & $\mathrm{P}$ & Sh, D & - & $\mathrm{R}$ \\
\hline Bregmaceros catulus & $\mathrm{P}$ & $\mathrm{Sh}$ & - & - \\
\hline Melanonus triangulus & $\mathrm{P}$ & $\mathrm{D}$ & - & $\mathrm{R}$ \\
\hline Palaeogadus cf. intergerinus & - & $? \mathrm{D}$ & - & - \\
\hline Coryphaenoides aff. guntheri & - & $\mathrm{D}$ & - & - \\
\hline
\end{tabular}

Table 2. Nominal species based on otoliths in the Ždánice and Subsilesian units and their distribution in the early Oligocene of the Central Paratethys (Brzobohatý 1967, 1982; Nolf \& Brzobohatý 1994; Brzobohatý \& Krhovský 1998) and the Mediterranean (Nolf \& Steurbaut 2004, Nolf \& Girone 2008). Abbreviations: P - Pouzdřany Marl; Sh. - Sheshory Mb.; D Dynów Mb.; PM - pebbly mudstones; K - Kiscell Clay; R Ranzano Fm. mudstone from the Jatný MB067 contained abundant planktonic foraminifers redeposited from various levels of the Eocene. Some benthic species like Uvigerina farinosa Hantk. and Bolivina trunensis Hof. indicate, anyhow, the Oligocene age. Also, pebbly mudstone from the Hluchová MB028 section seems to be the Oligocene based on the presence of planktonic foraminifer Tenuitella brevispira (Subb.).

\section{Conclusions}

1) Two fish otolith associations were documented in the Oligocene of the Subsilesian Unit at Bystřice nad Olší: lower-slope "Hluchová fauna" and upper-slope "Jatný fauna".

2) The "Hluchová fauna" from the Hluchová section are abundant and well preserved. This association is dominated by deep-sea taxa without neritic elements. It is interpreted as an in situ assemblage of the lower continental slope. The similarity with the deep-water component of the Pouzdřany Marl and the presence of 'Phosichthys' triquetrus, known only from this level, speak for the lower Oligocene age of the fauna. Fifty percent of the taxa from the Hluchová section occur also in the Ranzano Formation (Northern Apennines) with rich lower Oligocene deep-water teleostean fauna. The palaeobathymetric nature of the "Hluchová fauna" corresponds with the ecostratigraphic Zone IPM1 of the Polish Outer Flysch Carpathians including the Jamna Dolina, Kotów and Dynów members of the Menilite Formation (= NP22 to lowermost NP23 zones).
3) The otoliths of the "Jatný fauna" from the Jatný section are less numerous and poorly preserved (corroded). Stratigraphic interpretation of this fauna is problematic and reworking from the Eocene cannot be excluded.

4) Fish otoliths from the Oligocene of the Subsilesian and Ždánice units bring evidence about palaeomediterranean deep-water fish fauna with an oceanic character, strictly different at generic or higher levels from the modern Mediterranean fauna.

5) Cutthroat eel (?Synaphobranchidae) from the pebbly mudstones of the Subsilesian Unit represents probably the first fossil occurrence of the family.

\section{Acknowledgements}

The study of otolith fauna was supported by the project MSM0021622412 and preparation of the manuscript from the CGS research project 322400: "Selected taphocoenoses of the Mesozoic and Cenozoic".

\section{References}

Berggren, W.A. \& Pearson, P.N. 2005. A revised tropical to subtropical Paleogene planktonic foraminiferal zonation. The Journal of Foraminiferal Research 35(4), 279-298. DOI 10.2113/35.4.279

Brzoвонatý, R. 1967. Die Fisch-Otolithen aus den PouzdřanySchichten. Acta Musei Moraviae 52, 121-168.

BRzoBohatÝ, R. 1981. Izolované rybí zbytky z menilitových vrstev ždánické jednotky na Moravě. Zemni Plyn a Nafta 26(1), 79-87. 
BrzoвонатÝ, R. 1982. Die bisher älteste tertiäre Otolithenfauna (Teleostei) der Westkarpaten. Acta Universitatis Carolinae, Geologica, Pokorný Vol. 4, 341-355.

BrzoвонатÝ, R. 1986. Einige neue Arten von Knochenfischen (Teleostei, Otolithen) aus dem Westkarpatischen Tertiär. Acta Musei Moraviae 71(1-2), 55-71.

Brzobohatý, R. \& Kalabis, V. 1978. Biostratigrafické korelace v paleogénu a neogénu na základě ichthyofauny. Zemní Plyn a Nafta 23(4a), 533-542.

Brzobohatý, R. \& KrhovskÝ, J. 1998. A synopsis of the teleost taxa from the Pouzdřany Formation (West Carpathians, Pouzdřany Unit, Early Oligocene). Zemní Plyn a Nafta 43(2), 279-289.

Brzobohatý, R. \& Nolf, D. 1995. Diaphus otoliths from the European Oligocene (Myctophidae, Teleostei). Bulletin de l'Institut royal des sciences naturelles de Belgique, Sciences de la Terre 65, 257-268.

CichA, I. 1968. Moutnice - Ždánice nappe, Menilitic Formation, Upper Eocene, p. 43. In Cicha, I., Schmidt-Thomé, P., Janoscher, R. \& Prey, S. (eds) Problems of Flysch and Molasse Complexes. International geological congress, XXIII Session, Prague 1968. Guide to Excursion 26 AC. Geological Survey of Czechoslovakia, Prague.

Ciobanu, M. 1977. Fauna fossila din Oligocenul de la Piatra Neamt. 159 pp. Editura Academiei Republicii Socialiste Romania, Bucuresti.

Cohen, D.M. 1958. A revision of the fishes of the subfamily Argentinidae. Bulletin of the Florida Museum of Natural History, Biological Sciences 3(3), 93-172.

DAniltshenKo, P.G. 1947. O fylogeneticheskikch svjazach mezhdu rodami Palaeogadus i Merluccius. Doklady Akademii Nauk SSSR 58(4), 659-662.

Fedotov, V.F. 1976. Gadidae of the Paleogene-Neogene from the USSR. 72 pp. Nauka, Moskva.

Froese, R. \& Pauly, D. 2018. Fishbase. http://www.fishbase.org, version $(03 / 2018)$

GiLl, T.N. 1884. On the anacanthine fishes. Proceedings of the Academy of Natural Sciences of Philadelphia 36, 167-183.

Girone, A. 2003. The Pleistocene bathyal Teleostean fauna of Archi (Southern Italy): Palaeoecological and palaeogeographic implications. Rivista Italiana di Paleontologia e Stratigrafia 109(1), 99-110.

Girone, A., Nolf, D. \& Cappetta, H. 2006. Pleistocene fish otoliths from the Mediterranean Basin: a synthesis. Geobios 39, 651-71. DOI 10.1016/j.geobios.2005.05.004

GregorovÁ, R. 1997. Vývoj společenstev rybí a žraločí fauny v oligocénu Vnějších Západních Karpat (Morava) a jejich význam pro paleoekologii, paleobatymetrii a stratigrafii, 29-35. In Hladilová, Š. (ed.) Dynamika vztahů marinního a kontinentálního prostředí. Masaryk University in Brno.

Gregorová, R. 2013. Tajemné moře v Karpatech. 159 pp. Moravské zemské muzeum, Brno.

KoKen, E. 1884. Über Fisch-Otolithen, insbesondere über diejenige der norddeutschen Oligocän Ablagerungen. Zeitschrift der Deutschen geologischen Gesellschaft 36 , 500-565.

KoKen, E. 1891. Neue Untersuchungen an tertiären FischOtolithen. II. Zeitschrift der Deutschen geologischen Gesellschaft 43, 77-170.
Kotlarczyk, J., Jerzmańska, A., Świdnicka, E. \& WiszniowSKA, T. 2006. A framework of ichthyofaunal ecostratigraphy of the Oligocene-Early Miocene strata of the Polish Outer Carpathian Basin. Annales Societatis Geologorum Poloniae 76, 1-111.

KRHOVSKÝ, J. 1981. Mikrobiostratigrafické korelace vnějších jednotek flyšového pásma a vliv eustatických změn na jejich paleogeografický vývoj. Zemní plyn a nafta 26(4), 665-688.

Krhovský, J., Adamová, J., Hladíková, J., Maslowská, H. 1992. Paleoenvironmental changes across the Eocene/Oligocene boundary in the Ždánice and Pouzdřany Units (Western Carpathians, Czechoslovakia): the long-term trend and orbitally forced changes in calcareous nannofossil assemblages. Knihovnička ZPN, 14b(2), 105-187.

KUČERA, M. 1994. Foraminifery spodního oligocénu pouzdřanské jednotky z lokality Pouzdřany "U šipku”. 94 pp. Master thesis, Charles University Prague, Czech Republic.

Lin, Ch.-H., Brzobohatŕ, R., Nolf, D. \& Girone, A. 2017. Tortonian teleost otoliths from northern Italy: taxonomic synthesis and stratigraphic significance. European Journal of Taxonomy 322, 1-44. DOI 10.5852/ejt.2017.322

Lin, Ch.-H., Nolf, D., Steurbaut, E. \& Girone, A. 2016. Fish otoliths from the Lutetian of the Aquitaine Basin (SW France), a breakthrough in the knowledge of the European Eocene ichthyofauna. Journal of Systematic Palaeontology 15(11), 879-907. DOI 10.1080/14772019.2016.1246112

MartinI, E. 1971. Standard Tertiary and Quaternary calcareous nannoplankton zonation, 739-785, In FARINACCI, A. (ed.) $2^{\text {nd }}$ Planktonic Conference Roma 1970, Vol. 2, Editioni Tecnosciencia, Rome.

Menčík, E., Adamová, M., Dvořák, J., Dudek, A., Jetel, J., Jurková, A., Hanzlíková, E., Houša, V., Peslová, H., RyBÁŘovÁ, L., ŠmíD, B., ŠEbesta, J., TyRÁČeK, J. \& VAš́íčEK, Z. 1983. Geologie Moravskoslezských Beskyd a Podbeskydské pahorkatiny. 304 pp. Ústřední ústav geologický, Praha.

Nelson, J.S., Grande, T.C. \& Wilson, M.W.H 2016. Fishes of the World. Fifth edition. 707 pp. John Wiley \& Sons, New Jersey. DOI 10.1002/9781119174844

Nolf, D. 1977. Les Otolithes de l'Oligo-Miocene Belge. Annales de la Société Royale Zoologique de Belgique 106(1976/1), 3-119.

Nolf, D. 1985. Otolithi Piscium, 1-145. In Schultze, H.-P. (ed.) Handbook of Paleoichthyology 10. Fischer Verlag, Stuttgart.

NolF, D. 1988. Les otolithes de téléostéens éocenes d'Aquitaine (sud-ouest de la France) et leur intéret stratigraphique. Academie royal de Belgique, Mémoires de la classe des sciences, collection in-4 $4^{\circ}, 2^{\circ}$ série, 19(22), 1-147.

Nolf, D. 2004. Otolithes de poissons aptiens du Maestrazgo (povince de Castellon, Espagne orientale). Bulletin de l'Institut royal des sciences naturelles de Belgique, Science de la Terre 74-(supplement), 101-120.

NolF, D. 2013. The diversity of Fish otoliths, past and present. 222 pp. Royal Belgian Institute of Natural Sciences, Brussels.

Nolf, D. \& Brzobohatý, R. 1994. Fish otoliths from the Late Oligocene (Eger and Kiscell Formations) in the Eger area (northeastern Hungary). Bulletin de l'Institut royal des sciences naturelles de Belgique, Sciences de la Terre 64, 225-252.

Nolf, D. \& Brzobohatý, R. 1996. Oceanic fish otoliths across 
the Oligo-Miocene boundary in Europe. Giornale di Geologia 3, 58(1-2), 165-170.

Nolf, D. \& Brzobohatý, R. 2002. Otolithes de poissons du Paléocanyon de Saubrigues (Chattien à Langhien), Aquitaine méridionale, France. Revue de Micropaléontologie 45(4), 261-296. DOI 10.1016/S0035-1598(02)90049-8

Nolf, D. \& Brzobohatý, R. 2004. Otolithes de poissons du Miocène inférieur piémontais. Rivista Piemontese di Storia Naturale 25, 68-118.

Nolf, D. \& Girone, A. 2008. Early Oligocene fish otoliths from the Castellane area (SE France) and an overview of Mediterranean teleost faunas at the Eocene-Oligocene boundary. Neues Jahrbuch für Geologie und Paläontologie, Abhandlungen 248(2), 139-157.

DOI 10.1127/0077-7749/2008/0248-0139

Nolf, D. \& Steurbaut, E. 1983. Révision des otolithes de téléostéens du Tortonien stratotypique et de Montegibbio (Miocène Supérieur de l'Italie septentrionale). Mededelingen van de Werkgroep voor Tertiaire en Kwartaire Geologie 20(4), 143-197.

Nolf, D. \& Steurbaut, E. 1988. Description de la première faune ichthyologique exclusivement bathyale du Tertiaire d'Europe: otolithes de l'Oligocène Inférieur du gisement de Pizzocorno, Italie septentrionale. Bulletin de l'Institut royal des sciences naturelles de Belgique, Sciences de la Terre 57(1987), 217-230.

Nolf, D. \& Steurbaut, E. 2004. Otolithes de poissons de l'Oligocène inférieur du Bassin liguro-piémontais oriental, Italie. Rivista Piemontese di Storia Naturale 25, 21-68.

Pauca, M. 1929. Vorläufige Mitteilung über eine fossile Fischfauna aus dem Oligozän-Schiefern von Suslanesti (Muscel). Bulletin de la Section Scientifique Académie Roumaine 12, 112-120.

Pauca, M. 1931. Zwei Fischfaunen aus den oligozaenen Menilitschiefern von Mähren. Annalen des Naturhistorischen Museums in Wien 46, 147-152.

Pícha, F., Stráník, Z. \& KrejČí, O. 2006. Geology and hydrocarbon resources of the Outer Western Carpathians and their foreland, Czech Republic, 49-175. In GolonkA, J. \& Pícha, F. (eds) The Carpathians and their foreland: Geology and hydrocarbon resources. AAPG Memoir 84. DOI 10.1306/985607M843067

PřIKRYL, T. 2013. An annotated list of the Oligocene fish fauna from the Osíčko locality (Menilitic Fm.; Moravia, the Czech Republic). Acta Musei Nationalis Pragae, Series B, Historia Naturalis 69(3-4), 195-203.

Přikryl, T. \& Carnevale, G. 2017. An Oligocene toadfish (Teleostei, Percomorpha) from Moravia, Czech Republic: The earliest skeletal record for the order Batrachoidiformes. Bulletin of Geosciences 92(1), 123-131.

DOI 10.3140/bull.geosci.1662

Přikryl, T., Brzobohatý, R. \& Gregorová, R. 2016. Diversity and distribution of fossil codlets (Teleostei, Gadiformes, Bregmacerotidae): review and commentary. Palaeobiodiversity and Palaeoenvironments 96(1), 13-39. DOI 10.1007/s12549-015-0222-z

Přikryl, T., Schwarzhans, W. \& Kovalchuk, O. 2017. Lanternfishes (Myctophidae) with otoliths in situ from the
Early Oligocene of the Eastern Paratethys (western Ukraine). Neues Jahrbuch für Geologie und Paläontologie, Abhandlungen 285/2, 213-225. DOI 10.1127/njgpa/2017/0678

RoвbA, E. 1970. Otoliti del Tortoniano-tipo (Piemonte). Rivista Italiana di Paleontologia 76(1), 89-172.

Sauvage, H.E. 1880. Nouvelles recherches sur les Poissons fossiles découverts par M. Alby à Licata, en Sicile. Bibliothèque de l'Ecole des Hautes Etudes, Section des Sciences Naturelles 20,1-50.

Schubert, R.J. 1906. Die Fischotolithen des österr.-ungar. Tertiärs III. Jahrbuch der Kaiserlich-königlichen geologischen Reichsanstalt 56(3-4), 632-706.

Schubert, R.J. 1908. Die Fischotolithen des Pausramer Mergels. Zeitschrift des Mährischen Landesmuseums 8(1-2), 103-120.

Schwarzhans, W.W. 1994. Die Fisch-Otolithen aus dem Oberoligozän der Niederrheinischen Bucht. Systematik, Palökologie, Paläobiogeographie, Biostratigraphie und Otolithen-Zonierung. Geologisches Jahrbuch A 140, 3-248.

Schwarzhans, W. 2010. The Otoliths from the Miocene of the North Sea Basin. 352 pp. Backhuys Publishers, Leiden.

Smale, M.J., Watson, G. \& Hecht, T. 1995. Otolith Atlas of southern African marine fishes. Ichthyological Monographs 1, 1-253. DOI 10.5962/bhl.title. 141860

Steurbaut, E. 1982. Les otolithes de téléostéens du gisement de Peyrère à Peyrehorade (couches de passage de l'Oligocène au Miocène d'Aquitaine méridionale, France). Mededelingen van de Werkgroep voor Tertiaire en Kwartaire Geologie 19(2), 35-57.

Stráník, Z., JurÁšová, F. \& Peslová, H. 1981. Šitbořice Member of the Křepice-5 Borehole. Zemni Plyn Nafta 26(4), 701-710.

Stráník, Z., Krhovský, J., Brzobohatý, R., Hamršmíd, B. 1991. The Western Carpathians in South Moravia, 31-49. In HamršmíD, B. (ed.) Excursion Guide, $4^{\text {th }}$ INA Conference, Prague 1991. Knihovnička Zemního Plynu a nafty. Hodonín.

Šulc, J. 1932. Les otolithes du Paléogène des environs de Biarritz. Rozpravy Státního geologického ústavu Československé republiky 7, 1-94.

ŠvÁBenickÁ, L., Bubík, M., StrÁNík, Z. 2007. Biostratigraphy and paleoenvironmental changes on the transition from the Menilite to Krosno lithofacies (Western Carpathians, Czech Republic). Geologica Carpathica 58(3), 237-262.

Tuset, M.V., Lombarte, A. \& Assiz, C.A. 2008. Otolith atlas for the Western Mediterranean, North and Central Eastern Atlantic. Scientia Marina 72S1(Supl. 1), 1-203.

Vaillant, L.L. 1888. Expéditions scintifiques du Travailleur et du Talisman pendant les années 1880, 1881, 1882, 1883. Poissons. 406 pp. 28 pls. G. Masson, Paris.

Valenciennes, A. 1848. Argentina leioglossa. In Cuvier, G. \& Valenciennes, A. (eds) Histoire naturelle des poissons. Tome vingt et uniéme. Suite du livre vingt et uniéme et des Clupéoides. Livre vingt-deuxiéme. De la famille des Salmonoides. 536 pp. V. Levrault, Strasbourg.

WeILER, W. 1935. Nemopteryx kubacskai n. sp. aus dem Kleinzeller Tegel bei Budapešt', zugleich ein Beitrag zur Geschichte der Gattungen Nemopteryx Ag. und Merlucccius L. Palaeontologische Zeitschrift 17(1/2), 27-44.

DOI 10.1007/BF03041689 